\title{
What if Freire Had Facebook? A Critical Interrogation of Social Media Woke Culture Among Privileged Voices in Music Education Discourse
}

\author{
William J. Coppola \\ University of North Texas
}

In this paper, I critique the ways in which music education professionals-especially the privileged voices within our field-engage in dialogue through social media outlets such as Facebook. While social media has become a valuable and ubiquitous discursive tool within our field, especially in that it theoretically removes the "ivory tower" of dialogue in academia, here I critique its darker side. Were he alive today, I question how philosopher Paulo Freire would respond to the dialogical opportunities afforded by social media and the emergence of "woke culture." Particularly when engaging in the work of antiracism, I highlight how privileged music educators can silence any dialogue through their hostility or fragility alike through various forms of call-out culture, cancel culture, virtue signaling, and tone policing. I draw upon the full corpus of Freire's works to examine the overall veracity of these approaches to antiracist efforts and offer that Freire's pedagogy was interminably rooted in humility, love, and the pursuit of shared humanity.

Keywords: Paulo Freire, critical pedagogy, music education, dialogue, social media, woke culture, call-out culture.

$\mathrm{I}$

n contemporary music education discourse, social media outlets have carved out a grassroots-like arena for engaging in critical dialogue. Especially among marginalized communities, its popularity has worked to supplant the "ivory tower" of scholarship historically reserved for academic conferences and journal publications. With many professionals viewing these traditional academic spaces as out of touch and consistently White- and male-dominated, it might come as no surprise that much of the deep work of social justice reform is now taking place on social media outlets such as Facebook. Within music education, in particular, such digital spaces include Facebook groups like Social Justice Music Educators, 
Decolonizing the Music Room, ${ }^{1}$ NAfME's Cultural Diversity and Social Justice SMTE ASPA, The MayDay Group, and others. With group sizes spanning between 600 and 9,200 members each (at the time of this writing), these outlets represent an integral space for professional discourse among their members. Moreover, several of these spaces invite practicing $\mathrm{K}-12$ music educators, along with higher education faculty, to discuss best practices and deliberate over current issues in the field-a long-sought-after forum given the regrettable fissure often found between scholars and practitioners.

When social justice-minded educators attempt to engage in dialogue, they commonly summon the spirit of Paulo Freire, widely accepted to be one of the fathers of critical pedagogy. Freire's prolific ideas have paved the way for marginalized voices to name their oppression through the praxial use of dialogue-that is, dialogue which involves both critical reflection and action. At the core of praxis is a commitment to engage with others through a spirit of humanity, humility, and love (Freire 1970/2010). Freire fervidly believed in the importance of humanization at the center of his pedagogy. As Peter Roberts (2010) describes, "we humanize ourselves when we engage in critical, dialogical praxis; we dehumanize others (and ourselves) when we actively impede the pursuit of this vocation" (5, emphasis in original).

Indeed, behind the impersonal glow of a digital device, a darker side of social media seems to call our dialogical efforts-and thus the very nature of humanization-into question. Recent trends like "call-out culture," "cancel culture," "virtue signaling," and "tone policing" suggest a timely need to reflect upon Freire's ideal of humanization and question at what ends it should be imagined. Do such acts humanize by bringing us closer to a shared social justice vision, or do they dehumanize, as Roberts offers, by impeding upon our dialogical ethos and liberatory aims?

Particularly when White and White-presenting music educators-already over-represented in our academic spaces-utilize the same resources as afforded to all through social media, they have the potential to overpower those that most need to be heard: the voices of the marginalized. ${ }^{2}$ When these exchanges become riddled with either mean-spirited "call-out" and self-congratulatory "virtue signaling" behaviors on the one hand, or silencing tactics of "tone policing" on the other, dominant voices run the risk of becoming a vitriolic megaphone of whiteness, potentially drowning out the marginalized despite their intentions (see Hess 2017).

Coppola, William J. 2021. What if Freire had Facebook? A critical interrogation of social media woke culture among privileged voices in music education discourse. Action, Criticism, and Theory for Music Education 20 (1): 16-52. https://doi.org/10.22176/act20.1.16 
As Michael Apple (2013) warns, such White-centric acts, masked by the façade of allyship,

can just as easily run the risk of lapsing into the possessive individualism that is so powerful in this society.... Unless we are very careful and reflexive, it can still wind up privileging the White, middle class woman's or man's need for self-display.... We must be on our guard to ensure that a focus on Whiteness doesn't become one more excuse to re-center dominant voices and to ignore the voices and testimony of those groups of people whose dreams, hopes, lives, and their very bodies are shattered by current relations of exploitation and domination. (115)

Although Freire died in 1997, seven years before Facebook was invented, educators might imagine how Freire would have responded to a 21st century notion of dialogue as it occurs through impersonal digital spaces like Facebook. Our field can no longer ignore the ubiquitous power of social media as it permeates throughout our personal and professional spheres (Waldron et al. 2020), so it becomes a matter of moral and ethical importance to consider how we might choose to constructively engage in dialogue through professional social media discourse-particularly as we aim to bring antiracism and other social justice causes to the heart of the music education profession.

The goals of this paper are thus twofold. First, I seek to challenge privileged voices' prominent wielding of Freire's writings to support dialogical behaviors that err on the side of dehumanization. To this end, I highlight two opposing yet equally debasing tactics through which concepts of Freirean dialogue are misconstrued or altogether disregarded: one in which self-condoned brutish interactions are rationalized to be morally agreeable in the name of "wokeness," or alternatively, where knee-jerk defensiveness among White professionals centers their personal comfort over the social injustices experienced by marginalized groups. Through encounters with either, Freirean dialogue simply cannot function. Second, for those who wish to commit themselves more meaningfully to antiracist co-conspiratorship (as opposed to mere allyship), 3 I offer a reframed approach for engaging in the emancipatory potentials of dialogue through the exemplar of Paulo Freire-a man whose legacy of critical consciousness was built on humanity, humility, and love.

\section{Positionality and Audience}

While social media may be at times impersonal, it is certainly not apolitical. Our social identities are deeply complex and intersectional (Collins 2000, Crenshaw

Coppola, William J. 2021. What if Freire had Facebook? A critical interrogation of social media woke culture among privileged voices in music education discourse. Action, Criticism, and Theory for Music Education 20 (1): 16-52. https://doi.org/10.22176/act20.1.16 
1991), and through social media, certain aspects of our identities may either be reinforced or masked through a self-curated online presence (Abramo 2020, Shulman 2017). Thus, the concept of positionality, or the act of situating oneself within a social and political context with attention toward resulting power dynamics, is ever-present when speaking of the social dynamics enacted through social media culture. My positionality as a White, male, middle class, heterosexual, able-bodied older millennial situates me within a particular social position as both a music educator and social media user. 4 Further, I choose to allow for my presence on social media to visually reinscribe nearly all aspects of my dominant identity, resulting in social privileges that extend to my online identity as well. Therefore, I can be considered privileged in essentially all aspects of my social life, both on and offline.

As a result of my positionality, it must be noted that I, like all of my White colleagues, problematically engage in White Fragility (DiAngelo 2018) at a degree to which I cannot truly articulate or measure. It is a force that is often invisible to White people yet undeniably lucid to people of color. We can learn to recognize it with time, self-reflection, and an air of non-defensiveness, but we can never be fully rid of it. Therefore, I recognize that as much as I might remain aware of my penchant for White fragility, I acknowledge that these social blind spots likely manifest in unknowable ways throughout my writing. Moreover, as a result of these blind spots, I recognize that I cannot ethically attempt to speak of this topic on behalf of any marginalized voice. As this relates to my role in antiracist work, these realizations result in the following commitments: (1) listening more than I talk in an attempt to center the experiences of BBIA (Black, Brown, Indigenous, and Asian) 5 people rather than bringing attention to my own self-edification; (2) learning about antiracist work through personal research and conversations with other dominant voices to avoid burdening BBIA people with the task of educating their White colleagues; (3) working toward a comfort with discomfort (Hess 2018) so as to remain both non-defensively accepting of criticisms toward my role in perpetuating systemic racism and receptive to opportunities for self-growth; and (4) finding ways to engage in antiracist efforts in a way that both support and uplift BBIA people without drawing attention away from their efforts.

I also wish to remain clear that the intended audience of this critique is specifically White (and White-presenting) music educators who are themselves engaging in antiracist work on social media to any degree-from passive listening and learning (allyship) to engaged activism (abolitionism or co-conspiratorship). If we are

Coppola, William J. 2021. What if Freire had Facebook? A critical interrogation of social media woke culture among privileged voices in music education discourse. Action, Criticism, and Theory for Music Education 20 (1): 16-52. https://doi.org/10.22176/act20.1.16 
truly committed to supporting and uplifting BBIA voices, we must re-examine the actions we take in the name of allyship or co-conspiratorship. ${ }^{6}$ Do our behaviors center BBIA people or ourselves? Do our words bring more profit to our egos (not to mention our professional standings) than their livelihoods? Granted, it may very well be that the critiques I level in this paper will align favorably with the dialogical ethos among BBIA people as well, but I cannot ultimately make such claims. Rather, even as I address other White members of the music education community, I must remain ever aware of and sensitive to Juliet Hess's (2019) charge that "the question of who speaks as a critical pedagogue often reinscribes both patriarchy and Whiteness" (33). With this in mind, I humbly situate my writing within the essential contributions of music education scholars of color who have written prolifically on matters of diversity, equity, access, and inclusion-including Constance McKoy, Nicole Robinson, Carlos Abril, Joyce McCall, Jason Thompson, Nasim Niknafs, and Amanda Soto-as well as those whose work extends beyond "traditional" academic scholarship and into the field through music education activismincluding Brandi Waller-Pace, Lorelai Batislaong, Chris Mena, Eric Jimenez, Justin McLean, and countless others.

\section{Paulo Freire and Critical Pedagogy}

For many social justice-minded educators, Paulo Freire's name is tied almost exclusively to his most influential work, Pedagogy of the Oppressed (1970/2010). Without question, it is Freire's most prominent contribution to educational philosophy, and more than fifty years after its original publication it remains a core text among social justice activists and scholars (A M. A. Freire and Macedo 1998, Kirylo 2020). However, it is important to consider the social complexities with which Freire grapples in this seminal work, as well as his later contributions. Freire consistently stressed the importance of viewing subjects as historical beings, insisting, "men [sic] exist in time... Men are not imprisoned within a permanent 'today'; they emerge, and become temporalized" (Freire 1973, 3). Therefore, I begin with a brief detailing of Freire's upbringing as well as the social climate in which his work was written, to provide the necessary context for more deeply understanding Freire's contributions above and beyond his core text. Later, I will seek to uncover the central spirit of Freire-as a pedagogue, activist, and human being-in order to truly

Coppola, William J. 2021. What if Freire had Facebook? A critical interrogation of social media woke culture among privileged voices in music education discourse. Action, Criticism, and Theory for Music Education 20 (1): 16-52. https://doi.org/10.22176/act20.1.16 
understand how his legacy might survive in today's uniquely "dark times" (Giroux 2020).

Born in 1921 in Recife, Brazil, Paulo Freire's upbringing was very much a product of colonization, economic instability, and class inequality. Brazil had only abolished slavery three decades earlier and was the last country in the Western world to do so. Thrown into poverty and losing his father during adolescence, Freire grew up constantly food insecure and struggled to complete his schooling due to perpetual feelings of hunger-traumatic memories he recalled throughout his writings (Kirylo 2011). Reflecting upon his long-standing struggles with primarily classbased oppression, Freire's earliest ideas centered around the pursuit of humanization. Freire's grand concept of conscientização (conscientization, or "coming to consciousness") came to define his central contribution to educational philosophy (Kirylo 2020). Accused of being a communist and a subversive, he began writing his first major work, Education as the Practice of Freedom (1967) while in prison. After his release, Freire endured ongoing criticism from the Brazilian political right, driving him and his family (along with thousands of other Brazilians) into exile. Freire did not return home to Brazil until 1980, where he served as Secretary of Education in Sāo Paulo and spent his remaining years with his wife Nita (Ana Maria Araújo) until his death in 1997 (Kirylo 2011).

Distinguished from his infamous concept of "banking education," in which students' minds are passively "filled" through a one-directional process that reinscribes a duality between the oppressor and the oppressed, Freirean pedagogy requires students to "name their world," or recognize the conditions and inequities which have shaped their social positions. This process of naming one's world is not purely an intellectual exercise, but one rooted in constant reflection and actionan ongoing process called praxis. Without reflection, Freire (1970/2010) argues, action is merely activism, and without action, reflection is merely verbalism. Only when enacted together in the continuous process of praxis can true dialogue transpire.

In contrast to banking education, Freire (1970/2010) proposed a "problemposing" approach to education, where students' personal experiences, informed by their historically-situated bodies, are used to address "problems" through which dialogue ensues. These problems are rooted deeply within and cannot be disentangled from students' personal realities. Within Freire's oppressor-oppressed binary, humanization remains imprisoned; the oppressed first need to commit themselves

Coppola, William J. 2021. What if Freire had Facebook? A critical interrogation of social media woke culture among privileged voices in music education discourse. Action, Criticism, and Theory for Music Education 20 (1): 16-52. https://doi.org/10.22176/act20.1.16 
to their own transformation after naming their inequities, but this process is not one that can be undertaken in solitude among the oppressed. Rather, Freire (1970/2010) wrote that "this pedagogy ceases to belong to the oppressed and becomes a pedagogy of all people in the process of permanent liberation" (54). Part of this process, Freire offered, includes the removal of the oppressors as a dominant class, but must not result in the mere reversal of the binary (wherein the oppressed become the oppressors and the oppressors become the oppressed). Freire further insisted that liberation cannot take place in a climate of dehumanization. Throughout his writing, he argued that the pursuit of humanization requires people to reject their treatment as fixed objects and participate in their transformation as agentic subjects, and he identified a dehumanizing act as any which serves to deny this pursuit (44). Throughout this paper, I follow Freire's definition of dehumanization as any act which deliberately rejects one's subjectivity and attempts to reduce people to mere objects.

Freire's pedagogy is by no means meant to represent a systematic method because there can be no singular way for the oppressed to name their world and participate in their transformation (nor is there a singular way in which the marginalized experience oppression). Furthermore, the process of conscientização, pursued through critical praxis, can have no endpoint. As John Dale and Emery Hyslop-Margison (2010) articulated, "[praxis] has no particular destination; rather, [it] aims to ever-improve the human condition through measures of social justice, equality, and humanization" (98). Freire's critical pedagogy is therefore decidedly not dogmatic but rather is rooted in the lived experiences of those who enact it (A. M. A. Freire and Macedo 1998, Roberts 2000).

\section{Some Critiques of Critical Pedagogy}

It is necessary to note, especially when attempting to connect his work to antiracism, that Freire's contributions are certainly not without their critiques. First, some argue that critical pedagogy might exacerbate power hierarchies between the teacher and the student. In the process of problem-posing education, the question of who poses the problems could reinscribe hierarchical relationships, particularly given the implicit assumptions that (1) "students" (however they may be variously defined in a given teaching/learning scenario) cannot identify problems on their own, (2) the "teacher" knows what is best for the students, (3) the teacher-often

Coppola, William J. 2021. What if Freire had Facebook? A critical interrogation of social media woke culture among privileged voices in music education discourse. Action, Criticism, and Theory for Music Education 20 (1): 16-52. https://doi.org/10.22176/act20.1.16 
an outsider in relation to the student's lived experiences-somehow possesses an omniscient understanding of students' struggles and can name the circumstances of oppression for them, and (4) that students lack the ability to empower themselves without the teacher's intervention (see Hess 2019).

Other important critiques include the potential for reinscribing colonial relations and the privileging of Western epistemologies, as well as a lack of both feminist and racial perspectives (indeed, most contributors of critical pedagogy have been White men). Through her classroom efforts, Elizabeth Ellsworth (1989) found that that the abstract language of critical pedagogy might serve to emphasize dynamics of privileged voices, yielding Eurocentric, racist, sexist, classist, and other dominant narratives-especially when people of color are burdened with the edification of White students' ignorance (Razack 1998). Gloria Ladson-Billings (1997) further contends that critical pedagogy may fail to acknowledge the issue of race; she instead promotes critical race theory, which places cultural relevance at the center (see also Hess 2017, 2019 and Shevock 2015 for a comprehensive discussion of the critiques leveled against critical pedagogy, including its applications to music education).

While the challenges inherent within critical pedagogy remain ever-present and intricate, contributions from both Freire and his contemporaries have attempted to address several of these issues by integrating the praxial strengths of critical pedagogy with the epistemological contributions from theoretical frameworks that center racial, feminist, queer, and Indigenous knowledges (see Kirylo 2020). A long-time follower of Freire, bell hooks (1994) recalled Freire's openness to these criticisms, urging that such critiques should never "overshadow anyone's...capacity to learn from [his] insights" (49). As she recognized, the very nature of critical pedagogy invites critical interrogation rather than outright dismissal.

\section{Key Terms: Identifying the Derivatives of Woke Culture}

To envision how Paulo Freire might navigate today's social media culture, I first define several key terms that have become inseparably associated with social justice awareness in the 21st century. If Freire were to have Facebook, he would certainly need to understand and grapple with various phenomena including woke

Coppola, William J. 2021. What if Freire had Facebook? A critical interrogation of social media woke culture among privileged voices in music education discourse. Action, Criticism, and Theory for Music Education 20 (1): 16-52. https://doi.org/10.22176/act20.1.16 
culture, call-out culture, cancel culture, virtue signaling, moral grandstanding, performative allyship, and tone policing.

\section{What it Means to be "Woke"}

Altheria Caldera (2018) offers a broad history of the term "woke" in her article "Woke Pedagogy: A Framework for Teaching and Learning." The first usage of the term can be traced to Erykah Badu's 2008 song "Master Teacher," in which the chorus features the repeated lyrics "I stay woke." The term came to be generally associated with racial awareness, although its meaning has grown in complexity since its adoption by mainstream society. For example, the \#Woke and \#StayWoke hashtags originally used to raise awareness of racial injustices among Black youth (particularly within the Black Lives Matter movement around 2013) were soon coopted, mostly by White people, and relegated to "memefication" (Pulliam-Moore 2016). Being woke, in effect, quickly evolved from a genuine expression of one's awareness of racial injustice to a self-promotive way for (mostly White) people to disingenuously articulate their social consciousness. Maya Binyam (2016) likened the self-interested pursuit of wokeness to participating in the "Woke Olympics," where White people's obsession with appearing socially conscious becomes more about "winning" a game than actually inspiring social change. Binyam explained that the rules of the "game" include naming racism whenever it presents itself and condemning other White people who are "lagging behind":

successfully isolating your opponent is how you win the match. The best players are those who accumulate the names of people who "are" racist or of things that "have" racism in them. Woke Olympians, in other words, are frenetic curators of the most obvious aggressions; they launch a series of condemnations - in tweets, Facebook statuses, album reviews - and call it cultural critique.

In music education contexts specifically, Elizabeth Palmer (2018) argues that teachers who "stay woke" must have a level of consciousness that allows them "to be aware and subsequently knowledgeable about injustices" (23) that students face. It remains crucial, nonetheless, to be aware of how wokeness might be wielded both genuinely and appropriatively by its users.

\section{Call-Out Culture and Cancel Culture}

Coppola, William J. 2021. What if Freire had Facebook? A critical interrogation of social media woke culture among privileged voices in music education discourse. Action, Criticism, and Theory for Music Education 20 (1): 16-52. https://doi.org/10.22176/act20.1.16 
The performative derivative of woke culture is usually manifested through "callout" behaviors: when someone wishes to display their wokeness for the world to see, a common behavior is to publicly "call out" another person for their apparent lack of wokeness. Closely related to call-out culture is the notion of cancel culture, which represents a more extreme version of a call-out. "Canceling" occurs when a person (or organization) makes a statement or behaves in such a way that is considered so offensive that the only constructive solution is to shun or boycott them. A popular example includes the canceling of J.K. Rowling by many progressives in response to her posting several transphobic comments on Twitter. When someone is canceled, their behavior or standpoint is considered to be so problematic that dialogue is viewed as futile: the only suitable response is to symbolically erase their existence altogether.

As an alternative to the various forms of call-out culture, some have argued for the benefits of engaging in its opposite: to call-in by privately engaging in dialogue with the wrongdoer to protect them from public shame and humiliation (Saad 2020). However, while "call-ins" may present a more palatable learning opportunity for the transgressor, it can also problematically serve to reinforce feelings of comfort that cocoons White fragility (DiAngelo 2018).

\section{Virtue Signaling, Moral Grandstanding, and Performative Allyship}

Virtue signaling is also known by several other more-or-less synonymous terms, including moral grandstanding and performative allyship. Whereas woke, callout, and cancel culture are all reasonably straightforward to point out, the various forms of virtue signaling can be more challenging to detect because, in order to identify it, one must understand a person's core motivations for their actions, which can be challenging to objectively recognize. Despite one's best judgments, it may be impossible to know whether someone is expressing their wokeness out of a genuine desire to enact social change or for more self-absorbed and performative reasons.

Justin Tosi and Brandon Warmke (2016) provided a detailed account of how moral grandstanding (their preferred term) manifests from philosophical and social psychological perspectives. To them, a person might engage in moral grandstanding to either achieve a normative baseline (to appear as if they care about certain issues at a bare minimum) or to meet a loftier standard (to appear that they

Coppola, William J. 2021. What if Freire had Facebook? A critical interrogation of social media woke culture among privileged voices in music education discourse. Action, Criticism, and Theory for Music Education 20 (1): 16-52. https://doi.org/10.22176/act20.1.16 
care above and beyond their peers). Importantly, moral grandstanding does not necessarily presume a person's actual belief in their moral grandiosity. For instance, consider the politician who ardently conveys their moral viewpoints but clearly does not employ them in practice.

Tosi and Warmke (2016) articulate five notable manifestations of such grandstanding behaviors, each of which is relevant to woke culture. First is the act of (1) piling on, which occurs when a grandstander wishes to "get in on the action" regarding something that has already been said. For instance, they may rearticulate a seemingly woke comment in their own words in an attempt to achieve the same "woke points" as someone else. They may also (2) ramp up by making increasingly strong claims about the matter in question in order to communicate even greater outrage (thus implying superior morality). Third, they may (3) trump up by insisting on a moral problem where none reasonably exists, or express (4) excessive outrage, where the "wokest" person is the one who expresses the greatest degree of repugnance. Finally, (5) claims of self-evidence occur when a person signals that their morality is above public discourse; for example, responding to an offensive statement by commenting, "if you cannot understand how this is problematic, then I refuse to engage you any further."

Many people find overt forms of virtue signaling to be socially off-putting, but also admit that it is usually relatively harmless, especially compared to the social injustices that might otherwise go unreported. Indeed, there are certainly occasions in which virtue signaling might be beneficial, especially if the act of not grandstanding could be considered more harmful. Furthermore, Tosi and Warmke (2016) articulated three major risks to excessive virtue signaling. First, they argued that it could result in increased cynicism because people might stop believing the legitimacy of someone's moral discourse if everyone is just trying to protect their social capital. Second, it can result in what they call outrage exhaustion because "participants in public moral discourse will often have a more difficult time recognizing when outrage is a reliable signal of injustice, and will also find it increasingly difficult to muster outrage when it actually is appropriate" (211). Third, they warned against the deleterious effects of group polarization, wherein opposing viewpoints become increasingly divided toward polar extremes.

Specific to social media activity, I further identify a possible inverse risk-that is, a risk not resulting from the act of virtue signaling itself, but from one's selfprotective aims to avoid being negatively viewed as a virtue signaler. Because of an

Coppola, William J. 2021. What if Freire had Facebook? A critical interrogation of social media woke culture among privileged voices in music education discourse. Action, Criticism, and Theory for Music Education 20 (1): 16-52. https://doi.org/10.22176/act20.1.16 
apprehension that their actions might be viewed as moral grandstanding, one might choose to remain silent about important social justice matters that actually deserve focused attention. Consider, for example, the dangers of remaining silent (for fear of being viewed as a moral grandstander) when sharing important counter-narratives would otherwise be necessary for spreading awareness about a cause that may be differently presented (or left out altogether) by the news media. For instance, when two Black trans women-Riah Milton and Dominique "Rem'Mie" Fells-and one trans man-Tony McDade-were all murdered in May and June 2020, their deaths remained largely unreported by the traditional media. In response, social media served as a powerful tool for raising awareness about these deaths, particularly amidst the Black Lives Matter protests that were simultaneously occurring following the murder by police of George Floyd (which was extensively reported in traditional media). Awareness of these Black trans killings may never have become widely known if activists feared condemnation for signaling self-righteousness. Fortunately, there are occasions, such as this one, where the appearance of virtue signaling is considered a small price to pay in the name of advancing antiracist efforts.

\section{Avoiding Tone Policing}

Tone policing is an especially troublesome behavior, typically employed by dominant voices to further silence marginalized perspectives by disparaging the validity of their emotional investment within a discussion. As Mira Sucharov (2019) describes, tone policing.

originated in social justice circles to critique the phenomenon of someone inappropriately trying to control the way a marginalized person relays their experience of oppression...[they] accuse tone police of focusing on oppressed people's emotional intensity to deflect from the actual message in order to avoid doing something about oppression and marginalization. (119)

At its most innocuous, tone policing BBIA voices represents a harmful act of White fragility, wherein a White voice places greater value on objective facts (assumed to be unbiased and apolitical) over a marginalized person's lived experiences. At its most sinister, it functions as an outwardly manipulative way to "drain on the psyches of BIPOC" (Saad 2020). As Saad articulates, "tone policing reinforces white supremacist norms of how BIPOC are 'supposed' to show up. It is a way of keeping

Coppola, William J. 2021. What if Freire had Facebook? A critical interrogation of social media woke culture among privileged voices in music education discourse. Action, Criticism, and Theory for Music Education 20 (1): 16-52. https://doi.org/10.22176/act20.1.16 
BIPOC in line and disempowered... Tone policing is an insidious way of gaslighting BIPOC."

Tone policing often serves to shut down dialogue because, from either standpoint, it is argued to contain logical fallacies that compromise the validity of the ensuing argument. Specifically, the person engaging in tone policing is said to be making an ad hominem attack against their interlocutor by focusing on personal qualities (i.e., their emotionality) rather than the validity of their arguments. On the other hand, the victim of tone policing is said to be committing the logical fallacy of "appeal to emotion" (argumentum ad passions). Although it is often inappropriately wielded, the appeal to emotion fallacy is nevertheless one that should be examined critically, as it has fueled the emotion-based "Post-Facts" era on the political right (Lynch 2019). Yet, insofar as tone policing confronts a matter of civility-of reinforcing rules of politeness and decorum-one should critically evaluate whose civility it reinforces and whose voice it privileges within these discussions of oppression. Through such questioning, one can recognize that it overwhelmingly benefits privileged voices, because they have historically "set the playing field" for civility. Tone policing requires the oppressed to play the game according to the oppressor's rules. This apparent dialectical contradiction of tone policing requires critical examination in the pursuit of constructive dialogue.

\section{A Freirean Interrogation of Social Media Woke Culture}

Wokeness and Conscientização

Given what I have written about Freire's background and the development of his critical pedagogy, readers may reasonably infer several initial impressions that he might carry toward woke culture as manifested in social media settings. First, Freire likely would have been an outspoken proponent of woke culture as it originated among Black people but would have deeply problematized its whitewashing as it began to de-center Black voices in favor of White-centric self-proclamations of social awareness. Freire (1970/2010) would probably have viewed wokeness as a way in which Black voices "name the world" (88), which is the first step toward pursuing conscientização, or critical consciousness. However, he also likely would have seen White people's adoption of wokeness as a potentially well-intentioned but disingenuous attempt to proclaim their solidarity, simply because naming one's oppression can only be done by the marginalized, never for the marginalized

Coppola, William J. 2021. What if Freire had Facebook? A critical interrogation of social media woke culture among privileged voices in music education discourse. Action, Criticism, and Theory for Music Education 20 (1): 16-52. https://doi.org/10.22176/act20.1.16 
(131). As such, Freire would certainly classify White people's "awakening" toward the injustices against marginalized groups as necessary and constructive but would unlikely conclude that these efforts would ever make White people themselves "woke."

From this, one might conclude that wokeness and conscientização are essentially two sides of the same coin-one side forged by the Black community in the U.S., and the other by the poor and working class in Brazil. Both wokeness and conscientização require a commitment among marginalized voices to name and address the injustices present within their respective lived experiences. In drawing such parallels, one might recognize that just as conscientização can have no conceivable endpoint, neither can wokeness. If these parallels stand, an inherent paradox arises when making self-proclamations of wokeness today: the term implies a terminal point in the process; to be woke is to have achieved the endpoint of awakening. Thus, even etymologically speaking, one can never lay full claim to wokeness, just as Freire asserted that one can never lay full claim to conscientização. Put this way, as theoretically impossible as it may be for BBIA people to fully "achieve" wokeness (because no one will ever fully complete this journey), it may be categorically impossible for non-BBIA people to fully experience wokeness (because, regardless of their solidarity, it can never be their journey).

\section{Call-Out Culture, Cancel Culture, and (De)humanization}

In line with his possible support for wokeness as a modern manifestation of conscientização, Freire also would likely agree that call-outs are generally a necessary-albeit uncomfortable-part of engaging in transformative work. Throughout the corpus of his writing, Freire maintained that silence is an implicit act of dehumanization because it obstructs the liberatory efforts of the oppressed. There is accordingly no conceiving of Freire idly ignoring the oppressive words or acts leveled against marginalized communities. However, one can also remain relatively confident that Freire would condemn any call-out behaviors that might result in a malicious exchange, because he would view such acts as impeding the achievement of "openness" to the dialogical process, resulting in a similarly dehumanizing outcome. Freirean scholar Peter Roberts (2010) endorses this standpoint:

Freire's concept of educational dialogue is complex, multilayered, and not without its problems...but on one point we can be reasonably certain: Mean-spirited, vitriolic responses from one scholar to another...are at odds with the ideal Freire

Coppola, William J. 2021. What if Freire had Facebook? A critical interrogation of social media woke culture among privileged voices in music education discourse. Action, Criticism, and Theory for Music Education 20 (1): 16-52. https://doi.org/10.22176/act20.1.16 
had in mind. To write [about] or speak to another scholar with an underlying attitude of hostility and aggression is, from a Freirean perspective, a moment of sadness...and a difficult starting point for productive intellectual discussion. Dialogue of the kind Freire envisaged presupposes a willingness to listen, to enter into an educational conversation not in a dogmatic or reactionary manner but with humble respect for the Other. (8-9)

Without diminishing the significance of Roberts's point, White fragility often manifests through inaccurate interpretations of hostility or aggression whenever a response does not match what someone wishes to hear. For example, upon being "called out" for a problematic statement or stance, a transgressor will often find any response to be uncivil or hostile unless it placates their wrongdoing and absolves them of accountability. As hooks (1994) further reminds, the reproduction of White, bourgeois values in U.S. society often predetermines what might be interpreted as "dehumanizing" against hegemonic ideals of civility and respectability (178-9). Certainly, individuals must be honest with themselves and one another as they distinguish the line between accusations of hostility rooted in fragility on the one hand, and hostility rooted in genuine dehumanization on the other. While the former involves speaking truth to power (as uncomfortable as it may be), the latter deliberately serves to objectify. Shaming and ridiculing one's interlocuter through ad hominem attacks, for instance, or irrevocably associating them with a hate group such as the KKK, reduces them to objects and rejects their subjectivity for personal growth and transformation. This, to Freire, is the work of dehumanization.

Relatedly, Freire would almost certainly reject the notion of cancel culture because he would view it as a languid attempt to neglect one's dialogical responsibility. By definition, "canceling" someone is to refuse to engage them further in dialogue. As righteous as this decision may feel, canceling effectively represents the end of the dialogical road, prohibiting the potential for any emancipatory outcome to be further pursued. To this end, Freire (1970/2010) asserts that those who avoid such encounters "treat others as mere objects; instead of nurturing life, they kill life; instead of searching for life, they flee from it. And these are oppressor characteristics" (129, italics in original). Thus, similar to vitriolic call-outs, "canceling" someone denies them as subjects and reduces them to immutable objects.

Nonetheless, in affirming the racial criticisms leveled against Freire's work, one should also recognize that there are occasions in which BBIA voices will be more entitled to participate in cancel culture than their privileged peers. BBIA

Coppola, William J. 2021. What if Freire had Facebook? A critical interrogation of social media woke culture among privileged voices in music education discourse. Action, Criticism, and Theory for Music Education 20 (1): 16-52. https://doi.org/10.22176/act20.1.16 
people who have been harmed by racial violence and trauma throughout their lives might strategically utilize cancel culture, not to dehumanize their interlocutors, but rather to humanize themselves by refusing to exhaust their emotional labor on someone who continuously commits violence through their ignorance. The distinction is crucial, as privileged voices typically cannot lay reasonable claim to this same trauma.

Freire questioned his role in antiracism several years after writing Pedagogy of the Oppressed. He grappled with these very concerns in Learning to Question (1989): "As an apparent White man...the question is to know if I am really against racism in a radical way. If I am, then I have a duty and a right to fight with Black people against racism" (in hooks 1994, 57). Moreover, Freire (1970/2010) acknowledged that "human existence cannot be silent, nor can it be nourished by false words...Human beings are not built in silence, but in word, in work, in actionreflection" (88). Through these words, Freire touched upon two important points: first, "silence" cannot lead to action or change, and thus he would likely consider some degree of call-out culture necessary. Second, his allusion to false words touches upon the inauthentic "false generosity" that Freire detested so much throughout the entirety of his writing (Freire 1970/2010; 2005). Such inauthenticity lies at the center of another unfavorable manifestation of woke culture: virtue signaling.

\section{The Ethics of Virtue Signaling}

Given what we know of his remarkable sense of humility (Darder 2017, A. M. A. Freire and Macedo 1998, Giroux 2020), Freire would have assuredly taken great issue with any act of social justice reflecting the self-interested, performative, or narcissistic motivations of an individual. He would likely share an annoyance with self-promotive acts of virtue signaling because these behaviors tend to become implicit efforts to refocus attention toward the person who most outspokenly proclaims their outrage. Depending on its core motivation, virtue signaling most often effectively serves as a narcissistic investment in one's social capital (Lynch 2019). However, virtue signaling may not always originate from vain motivations; defensiveness and White fragility may also serve as culprits. For example, an ally might attempt to protect oneself against "status threat," fearing that they will be viewed as "not woke" and/or racist. As Michael Lynch (2019) recognizes, "if you believe in

Coppola, William J. 2021. What if Freire had Facebook? A critical interrogation of social media woke culture among privileged voices in music education discourse. Action, Criticism, and Theory for Music Education 20 (1): 16-52. https://doi.org/10.22176/act20.1.16 
your inherent moral superiority, then mistakes must be defensively denied or explained away" (101). In response to their efforts to eschew any negative attention to themselves, allies will instead invite positive attention toward their virtuousness. However, despite their innocuous intentions, these acts only serve to re-center whiteness by moving the spotlight toward themselves and away from the experiences of a marginalized person's oppression (Apple 2013; Hess 2017, 2019).

Without reflection-Freire's dialogical counterpart to action-people may never come to recognize their complicity in silencing the oppressed through their grandstanding behaviors. They may be fully convinced that through their outspoken proclamations of injustice, they are aiding the cause and enlightening the masses. This may be so to some degree, but when their edicts remain merely performative (that is, motivated disproportionately by self-interest), they arguably go no further in actualizing lasting transformative ends. Freire (1970/2010) calls this the "false generosity of paternalism"-a device which can only benefit the privileged:

Pedagogy which begins with the egoistic interests of the oppressors (an egoism cloaked in the false generosity of paternalism) and makes of the oppressed the objects of its humanitarianism, itself maintains and embodies oppression. It is the instrument of dehumanization. (54)

To some degree, it may be human nature for self-interest to live at the heart of our every action (Leary 2004). We may never be able to fully disentangle our actions from our desires to "fit in" with our progressive colleagues: to be viewed as being "on the right side of history" and decidedly "not racist." We wish to proclaim, through Facebook statuses and comment threads, our belonging to a particular group, and we ascribe great value to earning and maintaining this invisible membership. In some ways, then, every public action on social media can be seen as signaling one's desired group affiliation, and individuals continuously proclaim their virtuous standpoints in order to maintain membership within that group (Lynch 2019). While such behaviors are typical manifestations of social life, they can become dehumanizing-and dangerously tribal-when they pit one group against another. Lynch (2019) claims that "an attitude becomes tribal...when it is not just shared by a group but is implicitly or unconsciously social in its contentthat is, experienced as part of a 'we' and directed at 'them"' (25).

Coppola, William J. 2021. What if Freire had Facebook? A critical interrogation of social media woke culture among privileged voices in music education discourse. Action, Criticism, and Theory for Music Education 20 (1): 16-52. https://doi.org/10.22176/act20.1.16 


\section{Tone Policing}

Freire would undoubtedly understand the deleterious effects of tone policing and would ardently oppose its usage among privileged voices toward marginalized groups, recognizing its function of silencing one end of an already asymmetrical dialogical relationship. Moreover, his later writings highlighted the importance of committing oneself emotionally to the liberation of the oppressed (see Freire 1997, 2005), and he believed that the Cartesian split between mind and body need not be viewed as opposing but as holistically intertwined (A. M. A. Freire 2001). Therefore, to overlook one's emotions would be to fail to authentically engage in Freirean dialogue. Roberts (2010) substantiates Freire's belief in the primacy of emotion:

For Freire, when we attempt to think in a disciplined way-to theorize, to argue, to reason-we simultaneously commit ourselves to an emotional process...we experience a range of emotions-sometimes frustration, sometimes joy, often (in the longer run, if not immediately) a sense of fulfillment. (44)

Freire's wife Nita shared a sentimental story that charmingly illustrates Freire's position on the matter. While at a dinner party in New York, Paulo was nervously asked by another guest how he could caress his wife's hand in public all evening. Despite the audience's collective gasp at the audacity of the posed question, Freire was not troubled whatsoever by it, and kindly responded that when he holds his wife's hand, it "does not interfere with my ability to reflect, but rather it deepens it," adding, "thinking is not incompatible with feeling and pleasure. Rather, they complement each other. We should not be so positivistic, but rather dialectic with our bodies as well!" (A. M. A. Freire 2001, 73).

It is crucial to heed these words in earnest because individuals cannot witness the authentic act of dialogue if they also tone police the emotionality of an interlocuter's lived experience. The injustices Freire faced throughout his life-leading up to his exile and continuing until his death-resulted in deep-seated anger. As Roberts would like us to recognize, "there is anger, of a kind, in some of Freire's publications (see Freire 2004), but there is also a certain intellectual gentleness, built on an ethic of love, that can be detected throughout his writing career" (8). Indeed, as Freire's wife shared in the prologue of Pedagogy of Indignation, "we cannot forget something Paulo always said-that all truly ethical and genuinely human actions are born from two contradictory feelings, and only from those two: love and anger" (Freire 2004, xxx-xxxi). Still, readers are left with a vibrant sense of love throughout his writings, and such loving sentiments-both toward the

Coppola, William J. 2021. What if Freire had Facebook? A critical interrogation of social media woke culture among privileged voices in music education discourse. Action, Criticism, and Theory for Music Education 20 (1): 16-52. https://doi.org/10.22176/act20.1.16 
oppressed and his oppressors-always appeared to win out over the anger he righteously felt (Darder 2017).

At the same time, just as Freire strongly believed in the importance of emotion, he equally acknowledged the crucial role that reason played within any dialogue. Freire (2005) warned that "we must dare so as never to dichotomize cognition and emotion" (3). He believed "with [his] entire body, with feelings, with passion, and also with reason" (Freire 1997, 30, emphasis added). The dialectical relationship between reason and emotion characterized much of Freire's life, and while it may not have been emphasized in Pedagogy of the Oppressed, it became increasingly pronounced through his later writings-thus illustrating the importance of arriving at Freire's spirit as a human and pedagogue, rather than basing conclusions on ahistorical interpretations of his singular works. Consequently, as much as I cannot imagine Freire overlooking the silencing effects of tone policing (and thus endorsing a positivistic argument based solely on reason), I equally cannot imagine him accepting an argument based on emotion alone.

As these ideas specifically relate to dialogues between a dominant and a marginalized voice, tone policing should generally be viewed as a dehumanizing tactic that is not in line with the ethos of Freirean dialogue. Yet, when both sides of the dialogue involve privileged voices, I more subtly problematize how this dialogical process plays out for two reasons. First, tone policing is typically employed in a fragile attempt to disregard a BBIA individual's experiences (Saad 2020). ${ }^{7}$ Even when the dialogical process only involves dominant voices, the potential for indirectly repudiating a BBIA person's voice is still ever-present. However, White allies cannot themselves stake any personal claim to these emotions because they have not lived through them, nor have the White colleagues with whom they are dialoguing. Certainly, the emotions an ally carries throughout their dialogical process will be both necessary and just, but their emotions remain incidental to the marginalized community on whose behalf they speak. Second, tone policing, by definition, is employed in an attempt to silence an interlocuter's argument. However, so long as both dominant voices are committed to the ongoing process of dialogue, both unconcerned with "winning" (and thus ending) the argument, it is possible to actively negotiate the balance between reason and emotion, without silencing one's argument but rather constructively focusing the dialectical equilibrium. Nevertheless, dogmatic conceptualizations of tone policing remain anti-dialogical (A. M. A. Freire \& Macedo 1998, Roberts 2000), so one ought to grapple with these issues

Coppola, William J. 2021. What if Freire had Facebook? A critical interrogation of social media woke culture among privileged voices in music education discourse. Action, Criticism, and Theory for Music Education 20 (1): 16-52. https://doi.org/10.22176/act20.1.16 
willingly in order to realize a notion of Freirean dialogue that remains productive and liberatory to all.

\section{A Pedagogy of Love and Humility}

In Reinventing Paulo Freire: A Pedagogy of Love, Antonia Darder (2017) highlights Freire as a man who viewed all teaching as an "act of love" (80)-that is, one that is both "the foundation of dialogue and dialogue itself" (Freire 1970/2010, 89). For Freire, the act of love includes truly listening to others and valuing their life experiences. This work requires that both parties consider the lived experiences of the other rather than oversimplifying how one's privilege or marginalization may have formed their knowledge and identity. Such dialogue requires "being open to the word of the other, to the gesture of the other, to the differences of the other" (Freire 1998, 107). It is important to note, however, that Freire's (2005) idea of love was certainly not "soft" or meek, but rather what he called an "armed lovethe fighting love of those convinced of the right and the duty to fight, to denounce, and to announce" (74). Freire never acquiesced to the problematic stances of his transgressors but rather maintained an ethic of "tough love" through high expectations, tempered with understanding and patience.

Freire believed that love for one another represented an essential precondition to both dialogue and liberation because within the act of love exists the commitment to solidarity. Indeed, for Darder (2020), one could not meaningfully interpret Freire without an understanding of his deep love for others. As she reminisced, "never had another educational theorist so fearlessly given the question of love such primacy in his philosophy, pedagogy, or politics" (236). Throughout her writing, Darder compellingly lays out how Freire's pedagogy was far more than merely a pedagogy of the oppressed, of liberation, of hope, of indignation, or of freedom (as his various books were titled); at its core, his was always a pedagogy of love. Still, as is evident from his earliest writings, Freire believed that love could not exist without humility.

\section{Toward a Pedagogy of Humility}

Any attempt to articulate the central spirit of Paulo Freire as a philosopher, educator, activist, and human being must call attention to both his admirable capacity for love and his interminable sense of humility. Indeed, this was the first quality

Coppola, William J. 2021. What if Freire had Facebook? A critical interrogation of social media woke culture among privileged voices in music education discourse. Action, Criticism, and Theory for Music Education 20 (1): 16-52. https://doi.org/10.22176/act20.1.16 
that Henry Giroux (2020) evoked about his first interaction with Freire: "Given Paulo's reputation as a powerful intellectual, I recall initially being astounded by his profound humility. I remember being greeted with such warmth and sincerity that I felt completely at ease with him" (184). Freire's love for others was seemingly enabled by his humility, as he never adopted a superior attitude or mindset over others. As he wrote, "humility expresses...one of the few certainties that I am sure of, namely, that nobody is superior to anybody else" (Freire 1998, 108). Consequently, one need not dig too deeply to find the theme of humility imbued throughout his full corpus of works. It is important to clarify, however, that Freire conceived of humility purely in positive terms and did not associate it with lowliness, shame, or embarrassment, as it is often viewed in some religious and philosophical contexts (Button 2005). Rather, he associated it with courage, selfconfidence, self-respect, and respect for others (Freire 2005).

As he elucidated in Teachers as Cultural Workers, Freire (2005) strongly believed in the importance of practicing virtues within any dialogical process, considering them to be "indispensable qualities" among teachers and students. Importantly, Freire did not view virtues as fixed but rather as something capable of personal development through awareness and practice. There is frankly no conceiving of dialogue, at least in a Freirean sense, without the simultaneous practice of humility. In Pedagogy of the Oppressed (1970/2010), he makes this point unmistakably clear: "dialogue cannot exist without humility. The naming the of the world, through which people constantly re-create that world, cannot be an act of arrogance" (90). To Freire, humility remains inseparable from dialogue in several ways, requiring non-superiority, a sense of unfinishedness, open-mindedness, and an air of epistemological uncertainty.

\section{Non-superiority}

Freire believed that people cannot engage meaningfully in dialogue if they assume superiority over any other person. Such self-belief would amount to an incapacity to listen and a failure to demonstrate respect for the other:

Without humility, one can hardly listen with respect to those one judges to be too far below one's own level of competence...how can I listen to the other, how can I hold a dialogue, if I can only listen to myself, if I can only see myself, if nothing or no one other than myself can touch me or move me? ... Humility helps me avoid being entrenched in the circuit of my own truth. (Freire 1970/2010, 72)

Coppola, William J. 2021. What if Freire had Facebook? A critical interrogation of social media woke culture among privileged voices in music education discourse. Action, Criticism, and Theory for Music Education 20 (1): 16-52. https://doi.org/10.22176/act20.1.16 
Freire appeared to be particularly wary of the oppressor's humility, recognizing that a privileged voice that acts in an egocentric manner cannot effectively cooperate with the oppressed in naming their world. They fall victim to their own selfinterest-which is rarely, if ever-in the interests of the oppressed. As a result, false generosity will inevitably occur:

Men and women who lack humility (or have lost it) cannot come to the people, cannot be their partners in naming the world. Someone who cannot acknowledge himself [sic] to be as mortal as everyone else still has a long way to go before he can reach the point of encounter. (Freire 1970/2010, 90)

Gert Biesta (2013) further echoes Freire's sentiment, stating that "education is precisely concerned with the overcoming of this "original egocentrism," not by overriding or eradicating where [the person] is coming from but by establishing opportunities for dialogue with what or who is other" (3, emphasis in original). Thus, the more outspokenly one proclaims their wokeness through call-out and virtue signaling behaviors, the more crucial it becomes to scrutinize their humility (or lack thereof) in the process-to ensure that they are not centralizing their own identity at the expense of their colleagues.

\section{Unfinishedness}

Freire (1970/2010, 2015) always conceptualized the pursuit of humanity as unfinished and interminable. Humility, by definition, can only be actualized when a person comes to terms with this self-understanding, because if someone ever believes that they have intellectually "arrived," they will in effect prove nothing but their own arrogance. Therein lies the great paradox of humility: once we think we have it, we will find that we never did.

To consider one's "unfinishedness" also demands that they look to their origins as well, to critically examine how their life experiences might have shaped their perspectives and molded their social blind spots. Here, Henry Giroux's critique of neoliberal education-a system endured by both privileged and marginalized students alike within the United States-becomes relevant to the discussion. Neoliberalism has fabricated an educational ideal that effectively suppresses critical thought in favor of positivistic, apolitical, and post-racial viewpoints-effectively shrouding students' readiness for enacting their critical agency within society. As hooks (1994) points out:

Coppola, William J. 2021. What if Freire had Facebook? A critical interrogation of social media woke culture among privileged voices in music education discourse. Action, Criticism, and Theory for Music Education 20 (1): 16-52. https://doi.org/10.22176/act20.1.16 
Let's face it: most of us were taught in classrooms where styles of teachings reflected the notion of a single norm of thought and experience, which we were encouraged to believe was universal. This has been just as true for non-White teachers as for White teachers. Most of us learned to teach emulating this model. (35)

Because this expansive educational movement has affected all of us within the "neoliberal machine," we can view it as a broad-based form of subjugation within which other forms of systemic oppression-including racism, sexism, ableism, and others-further thrive (Giroux 2020). To this end, we must recognize that no matter how "far along" some activists may consider themselves, the vast majority will likely have originated from within the same intellectual starting point: one in which they were systematically discouraged from engaging in critical thinking and questioning the status quo throughout their formative educational years. Viewed this way, one person does not inherently possess greater intellectual superiority or more virtuousness than another; there are only those who have begun the work of dismantling their neoliberal foundations sooner than others.

This certainly does not exonerate White and White-identifying educators from their ignorance or accountability toward ongoing issues of racism, but we must also come to acknowledge, in the interest of engaging them further in dialogue, how their lived experiences may have inadequately prepared them to critically examine the systemic functioning of society. In so doing, we neither issue shame for their pasts nor make excuses for their continued ignorance as we guide productive dialogical efforts moving forward. By recognizing our journey within theirs, we practice compassion while upholding high expectations for their forthcoming development-all while keeping the burden of their self-education on themselves (as it is ultimately their responsibility). Giroux (2020) elaborates:

The pain and suffering of different groups under neoliberalism has to be understood not through shaming Whites ... but through efforts to unite these disillusioned groups across race, gender, and class divides... This shared suffering has to be mobilized through a new language of critique and hope. (250)

The notion that some allies or co-conspirators might arrogantly proclaim their advanced sense of wokeness would be viewed scornfully by Freire (1970/2010), who strongly asserts that "at the point of encounter there are neither utter ignoramuses nor perfect sages; there are only people who are attempting, together, to learn more than they now know" (90).

Coppola, William J. 2021. What if Freire had Facebook? A critical interrogation of social media woke culture among privileged voices in music education discourse. Action, Criticism, and Theory for Music Education 20 (1): 16-52. https://doi.org/10.22176/act20.1.16 


\section{Open-mindedness}

Humility requires open-mindedness because it is crucial for both acknowledging another's worldview and opening oneself up to criticism. I reiterate here how Freire valued the lived experiences of those with whom he dialogued, which he believed to be crucial to the process. If one adopts a closed-minded or absolutist regard toward their interlocutor, the best one could hope for will be a "monologue masquerading as a dialogue" (Apple 2013, 115), where convincing the other of one's truth becomes the only goal.

Rather than arrogantly "doubling down" on his viewpoints, Freire constantly modeled the importance of open-mindedness by justly considering all criticisms leveled against him and attempting to address them in his subsequent work. bell hooks (1994) recalled this quality when she confronted Freire directly (and publicly) about the sexist nature of his writings, which he conscientiously addressed in the moment and contended with in future writings. Similarly, Apple (2013) recalled that despite their common disagreements, Freire never had a sense of "winning" or "losing." In these moments, Freire reminded Apple that "one of the markers of greatness is how one deals with disagreement" (64).

\section{Epistemological uncertainty}

Finally, practicing humility in critical pedagogy crucially involves what Patti Lather (1998) calls a "praxis of not being so sure" (488). While a disposition of "uncertainty" (i.e., a lack of over-confidence) extends to the practice of humility generally, Lather speaks specifically of the tendency for critical pedagogy to be applied in a dogmatic or universalist fashion. Drawing upon the work of Jacques Derrida's "ordeal of the undecidable," she offers an understanding of critical pedagogy that "cannot define, finish, or close" (488) and therefore can never be definitively articulated. Hess (2019) adds that "certainty when implementing critical pedagogy has the potential to produce an opposite effect from the emancipatory ideal imagined by Freire...reminding us, as educators, of the importance of uncertainty and humility when enacting critical pedagogy" (30).

To otherwise adopt dogmatic conceptualizations of critical pedagogy is to work not only against Freire's intentions but, as some warn, to run the risk of fostering a form of micro-fascism (Freire 1997, Hess 2019, hooks 1994). Speaking specifically of this tendency in music education, Hess (2019) warned that "there is an

Coppola, William J. 2021. What if Freire had Facebook? A critical interrogation of social media woke culture among privileged voices in music education discourse. Action, Criticism, and Theory for Music Education 20 (1): 16-52. https://doi.org/10.22176/act20.1.16 
ever-present danger that social justice agendas in music education may, in fact, become a strict ideology that fails to allow for opposition or dissent, thus aligning with the definition of fascism" (146). hooks (1994) similarly recognized this tendency in academia at-large, and admired Freire's work for constantly maintaining the sense of openness necessary for avoiding such fascistic ways of thinking:

In so much of Paulo's work there is a generous spirit, a quality of open-mindedness that I feel is often missing from intellectual and academic arenas in U.S. society...I think the way we experience more profoundly the growing fascism in the world, even in so-called "liberal" circles, reminds us that our lives, our work, must be an example. (54)

These points draw upon Freire's (1970/2010) broader stance that non-dialogical approaches to emancipation may only serve to reinscribe the dominator's perspective, effectively making emancipatory efforts futile and/or fascistic:

revolutionary leaders who do not act dialogically in their relations with the people either have retained characteristics of the dominator and are not truly revolutionary; or they are totally misguided in their conception of their role, and prisoners of their own sectarianism, are equally non-revolutionary. They may even reach power. But the validity of any revolution resulting from antidialogical action is thoroughly doubtful. (127)

\section{Toward a More Dialogical Social Media Culture}

Social media can be seductive at reinforcing our beliefs and supporting our causes, whatever they may be (Lynch 2019). By self-curating our social circles online, we protect our personal comfort and build solidarity with like-minded others. Through the simple "liking" of a Facebook status, comment, or thread, we can throw our support behind a certain cause-a beguilingly simple act of endorsement that requires very little of us. Yet, such comforts can become prohibitive in the name of self-growth and performative in the name of social justice. The work of antiracism can neither be comfortable nor passive; we grow in our emancipatory commitments only by directly confronting our discomforts and checking our fragility at the door. Furthermore, our commitments cannot exist in the realm of social media alone, but must also extend into our communities and classrooms to become truly transformative-particularly because social media spaces such as Facebook can often serve to cocoon feelings of safety among the privileged, who might hide behind their screens as they defer personal responsibility to social justice causes in the "real world" (Abramo 2020). Learning to engage in humanistic

Coppola, William J. 2021. What if Freire had Facebook? A critical interrogation of social media woke culture among privileged voices in music education discourse. Action, Criticism, and Theory for Music Education 20 (1): 16-52. https://doi.org/10.22176/act20.1.16 
dialogue in social media settings, then, asks us not to merely be "good citizens" in virtual spaces alone, but to practice such empathy, humility, and love in all aspects of our social lives-both virtually and face-to-face.

In the interest of furthering antiracist education, along with any other social justice cause in our field, we ought to look to our social media consumption habits and question what unique purposes we wish them to serve. If we truly value social media's ability to facilitate an egalitarian setting for engaging in emancipatory work, then what good does it do to merely reinscribe the hierarchical structure of the academy, where those with the advanced degrees, and are overwhelmingly White and male, remain the most visible and outspoken? ${ }^{8}$ If social media is to serve as a meaningful discursive tool in our field, it must be used to amplify the voices of the marginalized-in this case, BBIA people-rather than our own. To communicate one's supposed wokeness through self-proclamations is to, once again, hog the playing field. This is precisely why, on social media as well as in our social lives, it becomes imperative to listen more than we talk, to seek to understand more than we seek to judge.

Engaging with others through the potentially impersonal format of social media requires scrutinizing our interpersonal commitments to one another in the process. Depending on one's experience and comfort with engaging with antiracism (or social justice issues in general), privileged educators can easily silence any dialogue through their fragility or hostility alike. Among those who might consider themselves less confident and/or experienced with confronting their antiracist responsibilities, White fragility can constantly loom in the periphery, causing defensiveness to rise in response to honest (yet uncomfortable) efforts to educate and inform. But fragility, defensiveness, and non-accountability (i.e., "I don't participate in racism!") cannot make for social change, and so they must be addressed before further progress can continue. Without these crucial steps, dialogue may cease on this end of the dialectical encounter.

On the other end of the encounter, for those who consider themselves experienced and comfortable with antiracist work, dialogue may likewise cease as soon as gaining social capital or "woke points" becomes more alluring than educating and promoting lasting social change. Through the perspective of one's ego, outspoken displays of wokeness in the form of call-outs or performative allyship might look and feel constructive, and indeed may introduce some degree of social awareness toward a particular issue, but the self-motivated nature of these exchanges

Coppola, William J. 2021. What if Freire had Facebook? A critical interrogation of social media woke culture among privileged voices in music education discourse. Action, Criticism, and Theory for Music Education 20 (1): 16-52. https://doi.org/10.22176/act20.1.16 
will often leave the process falling short of its potential. As such, in the name of coconspiratorship, one ought to look to the intended goals of these actions and critically examine how effectively the means justify the supposed ends. If one worthwhile aim of co-conspiratorship is the further promotion and transmission of its cause across the entire profession, then to what degree might a vitriolic approach to dialogue effectively realize this aim?9

Observationally, White music educators-admittedly succumbing to their fragility and egos-tend to "flee" such formative conversations upon being addressed derisively and intolerantly by their colleagues. As righteous as it may be to dismiss their fragility, and as equally problematic as their "White flight" remains, such exchanges will likely represent the end of the road for their continued potential in antiracist work. Can we, as fellow privileged allies, reckon this as a satisfactory aim in our work as co-conspirators? Indeed, we may, but we must ultimately part ways with Freire and his humanistic pedagogy if we are to do so.

One might argue, in response, that losing fragile followers along the journey is an unfortunate but necessary derivative of antiracist work. If someone is unable to "handle the heat," as it were, they simply need to "get out of the kitchen," as someone cannot both succumb to the comforts afforded to them by their White fragility while simultaneously serving the work of antiracism. Despite the legitimacy of this sentiment, are we willing to deny such people the chance to learn, to grow, to face their demons, and return with newfound perspectives with their comfort and fragility mindfully in-check? Certainly, one might expect no educator to turn their back on someone's genuine interest to commit themselves to these ends. As educators, furthermore, we understand instinctively that extending a hand is more persuasive than swatting a wrist. Upholding the humanity of all who are engaged in antiracist work does not mean coddling the comforts and vulnerabilities of our privileged peers. White educators who are truly invested in antiracist work must inevitably experience intense discomfort as they seek to relinquish their White fragility and grow according to the cause. Still, I dissociate "fragility" from "dehumanization" here and argue that the former does not insist upon the latter. Freire maintains that dehumanization results when someone is deliberately reduced to an object-fixed, unchangeable, doomed-and is in the process denied their subjectivity to transform themselves and others. One can be vehemently confronted with uncomfortable truths, then, without being vilified and relegated as a "lost cause."

Coppola, William J. 2021. What if Freire had Facebook? A critical interrogation of social media woke culture among privileged voices in music education discourse. Action, Criticism, and Theory for Music Education 20 (1): 16-52. https://doi.org/10.22176/act20.1.16 
In addition to Freire's teachings, Antonia Darder's (2017) pedagogy of love and bell hooks's (1994) engaged pedagogy both emphasize and prioritize the wellbeing of everyone within any educative process. These approaches all align favorably with Freire's commitment to the emancipatory and transformative power of love and caring (Darder 2017, 2020) and assuredly endorse only dialogical efforts that echo an ethos of love over vitriol, humility over arrogance, and patience over impetuousness. This certainly does not mean that Freire would have surrendered any opportunity to address social transgressions publicly, passionately, and even indignantly. But even through these efforts, he would have remained endlessly loving, caring, and patient toward all whom he encountered (Darder 2017, 2020, Giroux 2020, hooks 1994).

As educators, we ought to recognize the urgency of these commitments and heed Freire's actions in stride. Surely, any educator should without hesitation endorse an ethic of love and caring toward their students, because it is within these very environments that students are known to feel empowered, to thrive. How, then, might we prioritize such an ethic among our students but turn our backs on it when it comes to our peers? An ethic of care should not be viewed as merely developmental (for the youth alone), but essential to all human interactions. After all, as educators, we should certainly rebuke any teacher resorting to personal condemnations and mean-spirited criticisms toward their students. Would our colleagues not also be best motivated by an ethic of support and [tough] love over a spirit of denunciation and dehumanization?

To this end, I draw directly upon the legacy of Paulo Freire to denounce the at times mean-spirited social media culture that commonly erupts in professional music education social media contexts. As strongly as critical educators today criticize banking education as a result of Freire's incisive criticism of its social evils, it is my hope that critical educators will likewise decry a dialogical ethos of dehumanization, which he likewise detested (Darder 2017, Roberts 2010). Making antiracism a widespread educational standard, rather than the selective license of the "woke" alone, can occur only when we affirm the capability of every last music educator to see themselves in this essential work and prepare the music education profession at-large to take on their respective roles in the process. As Giroux (2020) obliges, "raising consciousness is not enough. [People] need to be inspired and energized to address important social issues" (212). Indeed, educators understand what it takes to inspire and energize students, and no teacher should contend

Coppola, William J. 2021. What if Freire had Facebook? A critical interrogation of social media woke culture among privileged voices in music education discourse. Action, Criticism, and Theory for Music Education 20 (1): 16-52. https://doi.org/10.22176/act20.1.16 
that shame and ridicule is the key to igniting such a flame within them. When we look inwards, we might find that our actions often fail to effectively or reasonably establish such ends; rather, they tend to dehumanize and serve our self-interest.

If we wish to revere Paulo Freire as a paragon of dialogue, then, we cannot do so by brandishing only one end of his praxis. All too often, we glorify the power of dialogue but execute it using only one side of our praxial obligation by acting on our words alone and failing to reflect on their impact. Freire remained consistently wary of this tendency, which is precisely why his focus on a praxis of action and reflection came to represent the only form of dialogue he viewed as emancipatory.

\section{TL;DR: ${ }^{10}$ In Summation}

To reach any sort of conclusion regarding Freire's position on today's social media woke culture, one cannot simply view him from a cross-sectional perspective. To seek an understanding of Freire as reflected through Pedagogy of the Oppressed alone, for example, would be to miss out on the depth of his legacy as it emanated throughout his years in exile and return to Brazil in the 1980s. Granted, his views from Pedagogy of the Oppressed did not necessarily change over the course of his later writings but rather became more incisive as he continued to face social injustices throughout his remaining years. His writings became more sensitive to feminist and racial perspectives as well, although arguably never to the point of a sufficient reckoning (Kirylo 2020). He continued to nuance his dialogical ideal, and in the process ascribed greater attention to the importance of sharpening one's virtuousness-especially humility, tolerance, open-mindedness, courage, and patience (Freire 2005).

Thus, we can remain relatively confident that were Freire still alive today, he might see clear parallels between modern woke culture (as established by the Black community) and his notion of conscientização. Both reflect one's continuous journey to pursue social consciousness toward systemic forms of subjugation. Freire would also probably view call-out culture as a mostly constructive way to engage in dialogue because to otherwise remain silent represents a form of violence toward marginalized communities. He would assuredly approve of social call-outs as long as they maintain the humanity of all involved, to ensure the persistence of the dialogical process. Conversely, he would almost certainly denounce any call-out behaviors that devolve into dehumanization through mean-spirited attacks, tacit

Coppola, William J. 2021. What if Freire had Facebook? A critical interrogation of social media woke culture among privileged voices in music education discourse. Action, Criticism, and Theory for Music Education 20 (1): 16-52. https://doi.org/10.22176/act20.1.16 
assumptions of superior social acuity, or any other act that serves to objectify. Likewise, he would detest the use of cancel culture among the privileged, as it refuses dialogue by its very definition. He would see value and opportunity in every dialogical encounter, even if one's viewpoints could be considered so morally contemptible that the prospect of progress may be unlikely.

Freire would also be critical of virtue signaling (and performative allyship/moral grandstanding), likely endorsing it only when the social benefits clearly outweigh one's self-interest. Of course, understanding internal motivations cannot be completed by external parties, so this work must be accomplished individually, introspectively, and honestly so as to truly understand the degree to which one's behavior is rooted in other-oriented rather than self-interested motivations. We also know that Freire deeply valued the lived experiences of everyone he encountered, including both the marginalized and the privileged, because he believed that seeking to understand others through their life experiences is essential to engaging them in dialogue. He viewed this as a critical act of "naming one's world" (Freire 1970/2010, 88)-the responsibility of all involved in the pursuit of social transformation. Finally, Freire would expectedly bemoan the use of tone policing and would share the perspective that it serves only to silence the valid emotionality of one's argument. He would instead claim that in any dialogical encounter, emotion can never be divorced from reason. Any cogent discussion, therefore, requires a delicate balance between emotionality and rationality; viewing either extreme alone is unproductive.

Throughout this paper, I have avoided drawing conclusions regarding how Freire's words might function within dialogues involving marginalized voices-and especially with BBIA music educators dialoguing with White colleagues. In such contexts, the dynamics of the dialogical encounter will expectedly shift. First of all, the historical trauma that BBIA people have had to endure at the expense of educating White peers has been historically problematic, particularly in social media formats, ${ }^{11}$ and I believe that Freire would be sensitive to this issue as well. As such, preserving a shared pursuit of humanity may not look the same within an encounter between a Black educator and a White colleague, especially given the deepseated social complexities of "White gaze" (see Yancy 2008), White-centric notions of civility, and the inequitable labor historically expected of BBIA people. To this point, Freire remained open-minded to how racial dynamics complicated his

Coppola, William J. 2021. What if Freire had Facebook? A critical interrogation of social media woke culture among privileged voices in music education discourse. Action, Criticism, and Theory for Music Education 20 (1): 16-52. https://doi.org/10.22176/act20.1.16 
critical pedagogy, but he recognized the shortcomings that his philosophy could not overcome with respect to certain racial and feminist perspectives.

Many will likely level critiques against the analyses I have put forth in this paper, and in the name of Freirean dialogue, I invite them unreservedly. Some may criticize that my inescapable White fragility has formulated an antagonistic perspective on the vitriolic nature of call-out culture. To this, I can only reasonably concur. Yet, I view the shortcomings of White fragility as a both/and rather than an either/or concern. In other words, the manifestations of White fragility in social media culture can be both deeply problematic and also need not result in the dehumanization of those who perpetuate it. Such behaviors merely shift the presence of an oppressor rather than work to abolish it.

As such, drawing deeply on Freire, I believe that White and White-identifying educators must do all they can to relinquish the toxic effects of their fragility in order for any dialogical encounter to be meaningful and productive. At the same time, I also believe that co-conspirators, committed to the call of making antiracist education a widespread commitment among all within the profession, must attempt to recognize their journey within their colleagues', to encourage compassionate ways for their peers to similarly overcome their fragile and oppressive stances and emerge as more empowered subjects-especially because this cannot be left to the labor of BBIA people alone.

To arrive at a thorough understanding of Paulo Freire is to view him not solely through Pedagogy of the Oppressed or any other of his seminal works, but to conclusively recognize his dialogical philosophy as one rooted in the shared and perpetually unfinished pursuit of humanity. His interminable sense of love, as demonstrated through his compassion, humility, tolerance, and patience, cannot be disconnected from a dialogue of praxial reflection and action. As such, in bringing Freire's voice to Facebook and other social media settings, educators must come to understand that however one chooses to engage with the efforts of social justice, it ought to center marginalized voices over our own. If we cannot reasonably say that our actions have served to amplify their voices, whether directly or indirectly, Freire might question why we chose to speak up at all.

Coppola, William J. 2021. What if Freire had Facebook? A critical interrogation of social media woke culture among privileged voices in music education discourse. Action, Criticism, and Theory for Music Education 20 (1): 16-52. https://doi.org/10.22176/act20.1.16 


\section{About the Author}

William J. Coppola is Assistant Professor of Music Education at the University of North Texas, where he currently teaches undergraduate and graduate courses in music teacher education, music education research, current issues in music education, and music education philosophy. Will's primary research interest examines the role of humility and egoism as they pertain to the ethical development of musicians and music educators. He was the recipient of the 2019 Hildegard C. Froelich Early Career Researcher Award, and his select publications have appeared in Music Education Research, Psychology of Music, Bulletin of the Council for Research in Music Education, and Update: Applications of Research in Music Education. He is also co-author of World Music Pedagogy Volume IV (Instrumental Music Education, 2018) and Volume VII (Teaching World Music in Higher Education, 2020), published by Routledge. He holds degrees from the University of Washington, New York University, and Hofstra University, and was previously an elementary music director with New York City Public Schools. www.WilliamJCoppola.com

\section{References}

Abramo, Joseph Michael. 2020. The "Social Justice Plot" in learning, consuming, and (re)creating music on social media. Journal of Popular Music Education 4 (2): 193-210. https://doi.org/10.1386/jpme_00022_1

Apple, Michael W. 2003. Freire and the politics of race in education. International Journal of Leadership in Education 6 (2): 107-18. https://doi.org/10.108o/ 13603120304821

Biesta, Gert J. J. 2013. The beautiful risk of education. New York, NY: Routledge.

Binyam, Mia. 2016. Watching the Woke Olympics. The Awl. https:// www.theawl.com/2016/o4/watching-the-woke-olympics/

Bradley, Deborah. 2006. Music education, multiculturalism, and antiracism: Can we talk? Action, Criticism, and Theory for Music Education 5 (2): 2-30. http://act.maydaygroup.org/articles/Bradley5_2.pdf

Button, Mark. 2005. "A monkish kind of virtue"? For and against humility. Political Theory 33 (6): 840-68. https://doi.org/10.1177/0090591705280525

Caldera, Altheria. 2018. Woke pedagogy: A framework for teaching and learning. Diversity, Social Justice, and the Educational Leader 2 (3): 1-11. Retrieved from https://scholarworks.uttyler.edu/dsjel/vol2/iss3/1

Coppola, William J. 2021. What if Freire had Facebook? A critical interrogation of social media woke culture among privileged voices in music education discourse. Action, Criticism, and Theory for Music Education 20 (1): 16-52. https://doi.org/10.22176/act20.1.16 
Collins, Patricia Hill. 2000. Black feminist thought: Knowledge, consciousness, and the politics of empowerment. New York, NY: Routledge.

Crenshaw, Kimberlé. 1991. Mapping the margins: Intersectionality, identity politics, and violence against women of color. Stanford Law Review 43 (6): 124199. https://doi.org/10.2307/1229039

Dale, John, and Emery J. Hyslop-Margison. 2010. Paulo Freire: Teaching for freedom and transformation: The philosophical influences on the work of Paulo Freire (Vol. 12). New York, NY: Springer.

Darder, Antonia. 2017. Reinventing Paulo Freire: A pedagogy of love. New York, NY: Routledge.

Darder, Antonia. 2020. Paulo Freire fifty years later: An afterword. In Reinventing pedagogy of the oppressed: Contemporary critical perspectives, edited by James D. Kirylo, 233-250. New York, NY: Bloomsbury.

DiAngelo, Robin. 2018. White fragility: Why it's so hard for white people to talk about racism. Boston, MA: Beacon Press.

Ellsworth, Elizabeth. 1989. "Why doesn't this feel empowering?” Working through the repressive myths of critical pedagogy. Harvard Educational Review 59 (3): $297-325$.

Freire, Ana Maria Araújo. 2001. Chronicles of love: My life with Paulo Freire. New York, NY: Peter Lang.

Freire, Ana Maria Araújo, and Donaldo Macedo. 1998. The Paulo Freire reader. New York, NY: Continuum.

Freire, Paulo. 1970/2010. Pedagogy of the oppressed (M. Ramos, trans.). New York, NY: Bloomsbury.

Freire, Paulo. 1973. Education for critical consciousness. New York, NY: Bloomsbury.

Freire, Paulo. 1997. Pedagogy of the heart. New York, NY: Bloomsbury.

Freire, Paulo. 1998. Pedagogy of freedom: Ethics, democracy, and civic courage. Lanham, MD: Rowman and Littlefield.

Freire, Paulo. 2004. Pedagogy of indignation. New York, NY: Paradigm.

Coppola, William J. 2021. What if Freire had Facebook? A critical interrogation of social media woke culture among privileged voices in music education discourse. Action, Criticism, and Theory for Music Education 20 (1): 16-52. https://doi.org/10.22176/act20.1.16 
Freire, Paulo. 2005. Teachers as cultural workers: Letters to those who dare teach. Boulder, CO: Westview Press.

Giroux, Henry A. 2020. On critical pedagogy (2nd ed.). New York, NY: Bloomsbury.

Hess, Juliet. 2015. Upping the "anti-": The value of an antiracist theoretical framework in music education. Action, Criticism, and Theory for Music Education 14 (1): 66-92. http://www.act.maydaygroup.org/articles/Hess14_1.pdf

Hess, Juliet. 2017. Critiquing the critical: The casualties and paradoxes of critical pedagogy in music education. Philosophy of Music Education Review 25 (2): 171-91. https://doi.org/10.2979/philmusieducrevi.25.2.05

Hess, J. 2018. A "discomfortable" approach to music education: Re-envisioning the "strange encounter." Philosophy of Music Education Review 26 (1): 2445. https://doi.org/10.2979/philmusieducrevi.26.1.03

Hess, Juliet. 2019. Music education for social change: Constructing an activist music education. New York, NY: Routledge.

hooks, bell. 1994. Teaching to transgress: Education as the practice of freedom. New York, NY: Routledge.

Kirylo, James D. 2011. Paulo Freire: The man from Recife. New York, NY: Peter Lang.

Kirylo, James D., ed. 2020. Reinventing pedagogy of the oppressed: Contemporary critical perspectives. New York, NY: Bloomsbury.

Ladson-Billings, Gloria. 1997. I know why this doesn't feel empowering: A critical "race" analysis of critical pedagogy. In Mentoring the mentor: A critical dialogue with Paulo Freire, edited by Paulo Freire, James W. Fraser, Donaldo P. Macedo, Tanya McKinnon, and William T. Stokes, 127-41. New York, NY: Peter Lang.

Lather, Patti. 1998. Critical pedagogy and its complicities: A praxis of stuck places. Educational Theory 48 (4): 487-97. https://doi.org/10.1111/j.17415446. 1998.00487.x

Leary, M. R. (2004). The curse of the self: Self-awareness, egotism, and the quality of human life. New York, NY: Oxford University Press.

Love, Bettina. 2019. We want to do more than survive: Abolitionist teaching and the pursuit of educational freedom. Boston, MA: Beacon Press.

Coppola, William J. 2021. What if Freire had Facebook? A critical interrogation of social media woke culture among privileged voices in music education discourse. Action, Criticism, and Theory for Music Education 20 (1): 16-52. https://doi.org/10.22176/act20.1.16 
Lynch, Michael P. 2019. Know-it-all society: Truth and arrogance in political culture. New York, NY: Liveright Publishing Co.

Razack, Sherene. 1998. Looking white people in the eye: Gender, race, and culture in courtrooms and classrooms. Toronto, ON: University of Toronto Press.

Palmer, Elizabeth S. 2018. Literature review of social justice in music education: Acknowledging oppression and privilege. Update: Applications of Research in Music Education 36 (2): 22-31. https://doi.org/10.1177/8755123317711091

Pulliam-Moore, Charles. 2016. How "woke" went from Black activist watchword to teen internet slang. Splinter. https://splinternews.com/how-woke-wentfrom-black-activist-watchword-to-teen-int-1793853989

Roberts, Peter. 2000. Education, literacy, and humanization: Exploring the work of Paulo Freire. Westport, CT: Greenwood Publishing Group.

Roberts, Peter. 2010. Paulo Freire in the 21st century: Education, dialogue, and transformation. New York, NY: Routledge.

Saad, Layla F. 2020. Me and white supremacy: Combat racism, change the world, and become a good ancestor. Naperville, IL: Sourcebooks.

Shevock, Daniel J. 2015. Reflections on Freirean pedagogy in a jazz combo lab. Action, Criticism, and Theory for Music Education 14 (2): 85-121. http://act.maydaygroup.org/articles/Shevock14_2.pdf

Shulman, David. 2017. The presentation of self in contemporary social life. Thousand Oaks, CA: Sage.

Sucharov, Mira. 2019. Public influence: A guide to op-ed writing and social media engagement. Toronto, ON: University of Toronto Press.

Tosi, Justin, and Brandon Warmke. 2016. Moral grandstanding. Philosophy \& Public Affairs 44 (3): 197-217. https://doi.org/10.1111/papa.12075

Waldron, Janice L., Stephanie Horsley, and Kari Veblen, eds. 2020. The Oxford handbook of social media and music learning. New York, NY: Oxford University Press.

Waller-Pace, Brandi, Lorelei Batislaong, Chris Mena, Syreeta Neal, Alice Tsui, and John Grimsley. 2020, June. Black Lives Matter, music ed, and current discourse: A discussion about dialogue in our field. Panel discussion, Decolonizing the Music Room. https://www.youtube.com/watch?v=BuLfTL7Ykwc

Coppola, William J. 2021. What if Freire had Facebook? A critical interrogation of social media woke culture among privileged voices in music education discourse. Action, Criticism, and Theory for Music Education 20 (1): 16-52. https://doi.org/10.22176/act20.1.16 
Yancy, George. 2008. Black bodies, white gazes: The continuing significance of race in America. Lanham, MD: Rowman \& Littlefield.

\section{Notes}

${ }^{1}$ In contrast to the other group pages listed here, Decolonizing the Music Room's (DTMR) mission specifically seeks to center Black, Brown, Indigenous, and Asian educators within the profession. As such, DTMR is a particularly inappropriate setting for dominant voices to center themselves through dialogue.

2 In this paper I wish to address all forms of social marginalization but will focus on racial oppression in particular, responding to the recent prevalence of discussions concerning antiracist education on social media (see Bradley 2006, and Hess 2015, for theoretical discussions of antiracism as it pertains to music education). I remain purposeful in my language throughout the paper to communicate whether I refer to either marginalization in general or antiracism specifically.

3 Particularly within social justice contexts, language shifts often in pursuit of the best words that both capture our intentions and center marginalized narratives. To that end, the terms "co-conspirator" and "abolitionist" will commonly be preferred over the term "ally." Whereas an ally can often be tied to inaction (particularly on social media), co-conspirators and abolitionists commit themselves more actively to the pursuit of dismantling systemic White supremacism within society (see Love 2019). Therefore, I use these specific terms purposively and not synonymously with allyship.

4 I also wish to note that my journey through social justice was late-coming and circuitous. I was raised in a relatively non-diverse working-class suburb of New York City and rarely felt compelled to think about matters of racial identity. A "progressive" to me, especially growing up in the 90s, was someone who was racially "colorblind." It was not until I began working with elementary children in Queens, New York that I finally began to understand many of these social issues that previously went unexamined. While I am certainly not proud of my "colorblind" upbringing, I have come to recognize its power in allowing me to empathize with the long and difficult process of overturning long-accepted truths and face the difficult and painful work of recognizing one's role in a systemically White supremacist society. It has also allowed me to appreciate the importance of acknowledging one's life experiences either to facilitate or complicate one's ability to open-mindedly address uncomfortable truths about systemic oppression within society.

5 The term "BBIA" was coined by Lorelei Batislaong, Deputy Director of Decolonizing the Music Room, in July 2020 (for further discussion see https://youtu.be/nMrlgoYmLUo). The terms "Black," "BBIA" (or “BIPOC," Black,

Coppola, William J. 2021. What if Freire had Facebook? A critical interrogation of social media woke culture among privileged voices in music education discourse. Action, Criticism, and Theory for Music Education 20 (1): 16-52. https://doi.org/10.22176/act20.1.16 
Indigenous, People of Color), and "marginalized" represent a continuum from most to least specific, and these terms will be used purposefully throughout this paper. For example, when I refer to Black or BBIA/BIPOC, I am referring to the lived experiences specific to these groups. When I use the term "marginalized," I include not just Black or BBIA identities but the full spectrum of the "matrix of domination" (Collins 2000) and their intersections (Crenshaw 1991), including race/ethnicity, gender identity, sexual orientation, ability, social class, religion, age, and so on.

${ }^{6}$ With these questions in mind, I in no way wish to present myself as someone who has "figured out" all of these answers. I recognize that I have often fallen tragically short with respect to my own antiracist responsibilities, and I continue to learn openly from these transgressions as they occur. I consequently place an emphasis on Freire's notion that critical consciousness is an everlasting journey.

7 While here I focus on the effects of tone policing among BBIA people in particular, tone policing is commonly employed in other social justice contexts; for example, in sexist rebuttals of feminist work.

8 I recognize the inherent irony of this statement coming from someone who also identifies as a White male music educator.

9 Again, I stress that I am speaking specifically to non-marginalized voices here. Where BBIA people are specifically involved in such dialogues, there is far greater rationale behind personal expressions of anger, both stemming from general frustration that their lived oppressions must be continually legitimized, as well as exasperation that their transgressors insist upon (and feel entitled to) their continued labor.

10 TL;DR is social media lingo for “too long; didn’t read."

${ }^{11}$ For a detailed description of these lived experiences, see Waller-Pace et al. (2020).

Coppola, William J. 2021. What if Freire had Facebook? A critical interrogation of social media woke culture among privileged voices in music education discourse. Action, Criticism, and Theory for Music Education 20 (1): 16-52. https://doi.org/10.22176/act20.1.16 